\title{
Peri-Urban Vertisol Properties as Influenced by Sewage and Bore Well Water Irrigation to Wheat (Triticum aestivum L.)
}

\author{
Salakinkop $\mathrm{SR}^{1^{*}}$ Hunshal $\mathrm{CS}^{2}$ and Patil $\mathrm{SL}^{3}$
}

${ }^{1}$ Department of Agronomy, University of Agriculture Sciences, Dharwad-580005, Karnataka State, India

${ }^{2}$ College of Home Science, University of Agricultural Science, Dharwad, Karnataka, India

${ }^{3}$ Central Soil and Water Conservation Research and Training Institute, Research Centre, Bellary, Karnataka, India

*Corresponding author: Salakinkop SR, Department of Agronomy, University of Agriculture Sciences, Dharwad-580005, Karnataka, India, Tel: 91-836-27479; E-mail: salakinkop@gmail.com

Rec date: Mar 04, 2014; Acc date: May 08, 2014; Pub date: May 15, 2014

Copyright: (c) 2014 Salakinkop SR, et al. This is an open-access article distributed under the terms of the Creative Commons Attribution License, which permits unrestricted use, distribution, and reproduction in any medium, provided the original author and source are credited.

\begin{abstract}
Field experiment was conducted in farmer's field near Agricultural Research Station, Dharwad, Karnataka State, India which was on the bank domestic sewage course in split plot design with three replications. Main plots included two types of lands (land irrigated with sewage water since 1970 and land irrigated with bore well water since 1992). Sub plots allotted with sources of irrigation consisted of sewage alone, bore well water alone (good water) and alternate sewage and bore well water. Analysis of sewage water for major and minor plant nutrients content revealed its potential as source of nutrients and water for crop growth. The soil physical properties especially bulk density and moisture holding capacity was improved significantly in sewage land over bore well irrigated land. Yield of wheat crop was positively correlated with these soil properties. There was reduction in soil $\mathrm{pH}$ in sewage land (7.24) over bore well irrigated land (7.65). The sewage irrigated land recorded significantly more bacterial and fungal colonies, dehydrogenase and alkaline phosphatase enzymes activities in soil. Sources of irrigation also differed significantly producing the highest microbial colonies, phosphatase and dehydrogenase enzymes activity in sewage water irrigation treatment followed by alternate irrigation as sewage water is good source of organic phosphorus (11.9-17.3 ppm). Irrigation with sewage water improved the performance of wheat crop as evidenced by higher grain yield $\left(4100 \mathrm{~kg} \mathrm{ha}^{-1}\right)$, protein content in grains $(12.8 \%)$, and dry gluten $(8.9 \%)$ compared to bore well water irrigation. Characterization of domestic sewage effluent showed that it can be used as source of irrigation water and top dressing nutrients.
\end{abstract}

Keywords: Sewage; Land; Irrigation; Bacteria; Fungi; Dehydrogenase; Phosphatase; Yield

\section{Introduction}

Sewage is defined as the waste water of a community [1]. Typical content of organic and inorganic suspended solids range from 100-350 $\mathrm{mg} \mathrm{l}^{-1}$. The suspended solids content is very important parameter in evaluating sewage for irrigation since they clog the soil pores and components of water distribution system. The composition of sewage of tropical and temperate countries was given by Mara and are as follows Table 1 .

These composition sewage effluents vary from time to time even at same location depending on developmental activities and volume of water used domestic purpose. Discharge of huge volume of waste water originated from domestic, commercial, industrial and other public uses into natural water sources makes them unfit for human usage. Every year about 300 million tons of organic waste is generating in India and fertilizer potential of this organic biomass has been estimated at around 15 million tons. In India, sewage farming alone could contribute 16,000 tons of nutrients per annum [2].

Thus irrigation with sewage provides the crop a cheap source of water, nutrients and at the same time avoids problem of its disposal $[3,4]$. Utilization of this domestic sewage for crop production may reduce the amount of water pollution as well as serve as water and nutrient source for crop. And same time numerous micro-organisms possibly present in the sewage water moves through the soil is of more concern. Evaluating the particular sewage on health of plant and soil is need of the hour in the context of safe recycling of waste water. Application of sewage caused reduction in yield of crops due to presence of plant pathogens [5,6]. Baraman [7] observed adverse effects of sewage irrigation on growth and yield of pulses and oil seeds. In contrast, sewage irrigation improved the yield of several crops [8-10]. Sewage irrigation supported the population of $\mathrm{N}$-fixers such as Azotobacter, Rhizobium and fungi involved in organic matter decomposition [11]. The plant pathogens present in sewage subjected to normal die-off which takes several weeks to few months [12].

With these ideas, a field experiment was conducted to study the effect of sewage irrigation on physico-chemical properties and microbial dynamics in the sewage irrigated soil vis-a-vis bore well water irrigation.

\section{Material and Methods}

\section{Description of location and experimental layout}

The field experiment was conducted on farmers field in Dharwad $\left(15^{\circ} 26^{\prime} \mathrm{N}\right.$ latitude, $75^{\circ} 07^{\prime} \mathrm{E}$ longitude, altitude of $678 \mathrm{~m} \mathrm{MSL}$ ), Karnataka state, India during winter seasons for two consecutive years. Experimental site receives a mean annual rainfall of $762 \mathrm{~mm}$ which is fairly distributed from April to December. Both, sewage irrigated land and bore well irrigated lands were silt clay loam. More than 80 million 
liters of waste water generating from Hubli-Dharwad twin cities, second largest in Karnataka State, India is mainly domestic origin. The sewerage system for Dharwad city was divided into four drainage streams, determined by topography of the city; Madihal, Hirekeri, Narendra and Lakamanhalli. Untreated sewage water of Dharwad joins to number of small streams on its way to Tupari a large stream which ultimately meets Malaprabha River, a main potable water source for Hubli - Dharwad city. It may continue to pollute all water sources on its course. Majority of farmers are unaware of its potentiality as a source of nutrients and in fact they have notion that sewage water will spoil their soil and crops grown even under good management system. The experiment was laid out in split plot design with three replications. Main plots constituted two types of lands (land irrigated with sewage since 1970 and land irrigated with bore well since 1992). These two types of lands were situated in contiguous, but separated by field bund. Bore well irrigated land had never received sewage irrigation and vice-versa. Sub plots allotted with sources of irrigation consisted of sewage alone, bore well water alone (best available water for irrigation) and alternate sewage and bore well water. The recommended dose chemical fertilizer to wheat crop was 100:75:50 $\mathrm{kg} \mathrm{N}, \mathrm{P}_{2} \mathrm{O}_{5}$ and $\mathrm{K}_{2} \mathrm{O}$ per hectare. These nitrogen, phosphorus and potash were applied in the form of urea, diammonium phosphate and muriate of potash respectively. The crop was harvested at 105 DAP. Grain yield and yield attributes were recorded at the time of harvesting. Treatment wise soil samples were collected before layout of experiment and after crop harvest for analysis of physico-chemical properties and microbial dynamics.

At each irrigation sewage effluent and bore well water were collected for characterization with respect its physico-chemical properties.

\begin{tabular}{|c|c|c|c|c|c|c|c|}
\hline \multirow[b]{2}{*}{$\begin{array}{l}\text { Component } \\
\text { s }\end{array}$} & \multicolumn{7}{|c|}{ Concentration (mg 1-1) } \\
\hline & $\begin{array}{l}\text { Kenya } \\
\text { (Nairo } \\
\text { bi) }\end{array}$ & $\begin{array}{l}\text { Kenya( } \\
\text { Nakur } \\
\text { h) }\end{array}$ & $\begin{array}{l}\text { India } \\
\text { (Kodung } \\
\text { aiyur) }\end{array}$ & $\begin{array}{l}\text { Peru } \\
\text { (Lim } \\
\text { a) }\end{array}$ & $\begin{array}{l}\text { Israel } \\
\text { (Herzli } \\
\text { ya) }\end{array}$ & $\begin{array}{l}\text { USA } \\
\text { (Alleno } \\
\text { wn) }\end{array}$ & $\begin{array}{l}\text { UK } \\
\text { (Yeo } \\
\text { ril) }\end{array}$ \\
\hline $\mathrm{BOD}\left(\mathrm{mg} \mathrm{l}^{-1}\right)$ & 448 & 940 & 282 & 175 & 285 & 213 & 324 \\
\hline $\begin{array}{l}\text { Total soluble } \\
\text { solids }\left(\mathrm{g} \mathrm{l}^{-1}\right)\end{array}$ & 550 & 662 & 402 & 196 & 427 & 186 & 321 \\
\hline $\begin{array}{l}\text { Total } \\
\text { dissolved } \\
\text { solids }\left(\mathrm{g} \mathrm{l}^{-1}\right)\end{array}$ & 503 & 611 & 1060 & 1187 & 1094 & 502 & - \\
\hline $\begin{array}{l}\text { Chlorides } \\
\text { (ppm) }\end{array}$ & 50 & 62 & 205 & - & 163 & 96 & 315 \\
\hline $\begin{array}{l}\text { Ammonical } \\
N(p p m)\end{array}$ & 67 & 72 & 30 & - & 76 & 12 & 29 \\
\hline
\end{tabular}

Table 1: Composition of sewage of tropical and temperate countries.

\section{Planting and after care}

Bread wheat variety Triticum aestivum, DWR-162 was planted at the seed rate of $150 \mathrm{~kg} \mathrm{ha}^{-1}$ in $22.5 \mathrm{~cm}$ row spacing on November 1st in both the years. Bore well water was provided immediately after planting for both the lands and thereafter the crop was irrigated (boarder strip) as per treatments based on crop critical stages approach for irrigation (crown root initiation, peak tillering production, flowering, grain formation, grain development and grain dough stage).Depth of water provided at each irrigation was $60 \mathrm{~mm}$. Crop was inter cultivated at 25 and 45 days after planting (DAP). Crop was top dressed two times with $30 \mathrm{~kg}$ nitrogen in the form of urea at boot leaf stage and at a thesis. Weeds were managed with post emergent spray of 2-4-D at the rate of 2.5 liters ha- 1 on 20 DAPS. One hand weeding and two inter cultivations were also carried out to keep weeds under control. The major pest of the region like termites and leaf rust were not notice on the crops in both sewage and bore well irrigated lands.

\section{Analysis of soil and plant samples for estimation of nutrients}

The soil samples collected from 0-30 cm depth after harvest of crop were analyzed for some of the physico-chemical properties. The procedures adopted for estimation and initial soil test results were

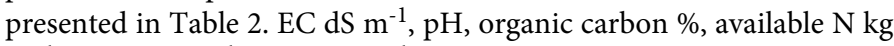
$\mathrm{ha}^{-1}, \mathrm{P}_{2} \mathrm{O}_{5} \mathrm{~kg} \mathrm{ha}^{-1}, \mathrm{~K}_{2} \mathrm{O} \mathrm{kg} \mathrm{ha}^{-1}$, DTPA extractable $\mathrm{Cu}$ ppm, Fe ppm, $\mathrm{Mn} \mathrm{ppm}$ and $\mathrm{Zn} \mathrm{ppm} \mathrm{in} \mathrm{sewage} \mathrm{irrigated} \mathrm{land} \mathrm{were} 0.42,7.3,0.86$, $235.8,29.5,458.6,1.61,6.50,18.50$ and 0.42 ; whereas for bore well irrigated land these values were $0.31,7.95,0.43,141.5,17.90,387.5$, $1.18,4.06,12.20$ and 0.23 respectively [13].

\begin{tabular}{|c|c|c|c|}
\hline Properties & $\begin{array}{l}\text { Sewag } \\
\text { e land }\end{array}$ & $\begin{array}{l}\text { Bore well } \\
\text { irrigated land }\end{array}$ & Method \\
\hline \multicolumn{4}{|l|}{ I. Physical properties } \\
\hline \multicolumn{4}{|l|}{$\begin{array}{l}\text { 1. Particle size } \\
\text { analysis }\end{array}$} \\
\hline Coarse sand (\%) & 6.1 & 6.5 & \multirow{4}{*}{$\begin{array}{l}\text { International pipette methoc } \\
\text { [14] }\end{array}$} \\
\hline Fine sand (\%) & 16.5 & 15.7 & \\
\hline Silt (\%) & 18.5 & 18.1 & \\
\hline Clay (\%) & 58.5 & 59.3 & \\
\hline $\begin{array}{l}\text { 2. Bulk density }(\mathrm{Mg} \\
\left.\mathrm{m}^{-3}\right)\end{array}$ & 1.23 & 1.32 & Core sampler method [15] \\
\hline \multicolumn{4}{|c|}{ II. Chemical properties } \\
\hline $\begin{array}{l}\text { Electrical } \\
\text { conductivity (dS m- } \\
\text { I) }\end{array}$ & 0.42 & 0.31 & EC bridge [16] \\
\hline $\mathrm{pH}$ & 7.3 & 7.95 & $\begin{array}{l}1: 2.5 \text { soil: water suspension } \\
\text { [16] }\end{array}$ \\
\hline Organic carbon (\%) & 0.86 & 0.43 & $\begin{array}{l}\text { Walkley and Black's wet } \\
\text { oxidation method [16] }\end{array}$ \\
\hline $\begin{array}{l}\text { Available N (kg ha- } \\
\text { ') }\end{array}$ & 235.8 & 141.5 & $\begin{array}{l}\text { Alkaline } \\
\text { method [17] }\end{array}$ \\
\hline $\begin{array}{l}\text { Available } \mathrm{P}_{2} \mathrm{O}_{5}(\mathrm{~kg} \\
\left.\mathrm{ha}^{-1}\right)\end{array}$ & 29.5 & 17.9 & Olsen's method [18] \\
\hline $\begin{array}{lll}\begin{array}{l}\text { Available } \\
\left.\mathrm{ha}^{-1}\right)\end{array} & \mathrm{K}_{2} \mathrm{O} & (\mathrm{kg} \\
\end{array}$ & 458.6 & 387.5 & Extraction with NH40AC [15] \\
\hline
\end{tabular}

Table 2: Methods employed to estimate physico-chemical properties of experimental soils

\section{Characterization of sewage and bore well water}

Sewage effluent samples collected during cropping season were analyzed for physico-chemical properties viz., $\mathrm{BOD}_{5}(\mathrm{ppm})$, total solids $\left(\mathrm{g} \mathrm{l}^{-1}\right), \mathrm{pH}$, electric conductivity $\left(\mathrm{dS} \mathrm{m}^{-1}\right)$, chlorides (me $\mathrm{l}^{-1}$ ), 
$\mathrm{SO}_{4}\left(\mathrm{me} \mathrm{l}^{-1}\right.$ ), total Kjeldal $\mathrm{N}$ (ppm), total $\mathrm{P}$ (ppm) according to Standard Methods proposed by American Public Health Association APHA [19]. The mean data were presented in Table 3. The COD concentration was determined by the closed reflux, colorimetric method (Standard Method (SM) 5220 D). The BOD (5) was determined using the manometric method (SM $5210 \mathrm{D}$ ), in which the sample was digested during 5 days of incubation on a shaker base at 20 $\pm 1^{\circ} \mathrm{C}$. The TDS were determined using SM $2540 \mathrm{~B}$, in which the samples were centrifuged at $4,000 \mathrm{rpm}$ for $20 \mathrm{~min}$ and dried to a constant weight at $105^{\circ} \mathrm{C}$. The samples were filtered within $12 \mathrm{~h}$ of collection, and the filter was frozen prior to extraction. Total coliform analyses were performed using a chromogenic medium. The samples were analyzed using the Quanti-Tray $\% / 2000$ Inc.) method and were incubated at $37^{\circ} \mathrm{C}$ for $24 \mathrm{~h}$. Yellow wells indicated total coliforms, and yellow/fluorescent wells indicated the presence of $E$. coli.

\begin{tabular}{|c|c|c|c|}
\hline Character & Value & Character & Value \\
\hline $\mathrm{pH}$ & 7.54 & $\mathrm{sO} 4\left(\mathrm{me} \mathrm{l}^{-1}\right)$ & 7.75 \\
\hline $\mathrm{EC}\left(\mathrm{dS} \mathrm{m}^{-1}\right)$ & 0.79 & Kjeldal N (ppm) & 29.2 \\
\hline Total solids $\left(\mathrm{g} \mathrm{l}^{-1}\right)$ & 708.5 & Total P (ppm) & 13.1 \\
\hline BOD5 (ppm) & 141.4 & Total K(ppm) & 54.7 \\
\hline Chlorides $\left(\mathrm{me}^{-1}\right)$ & 8.4 & $\mathrm{Ca}(\mathrm{ppm})$ & 10.85 \\
\hline $\mathrm{Mg}(\mathrm{ppm})$ & 6.38 & Mn (ppm) & 0.15 \\
\hline $\mathrm{Na}(\mathrm{ppm})$ & 47.6 & $\mathrm{Cd}(\mathrm{ppm})$ & BDL \\
\hline Zn (ppm) & 0.31 & $\mathrm{Ni}(\mathrm{ppm})$ & BDL \\
\hline $\mathrm{Cu}(\mathrm{ppm})$ & 0.16 & $\mathrm{Cr}(\mathrm{ppm})$ & 0.004 \\
\hline $\mathrm{Fe}(\mathrm{ppm})$ & 1.24 & $\mathrm{~Pb}(\mathrm{ppm})$ & 0.029 \\
\hline \multicolumn{4}{|c|}{ Microbial population in sewage water used for irrigation } \\
\hline Total bacteria colonies & $\begin{array}{l}12.5 \text { to } 15.5 \times \\
10^{-6}\end{array}$ & $\begin{array}{l}\text { Total } \\
\text { Actinomycetes }\end{array}$ & $\begin{array}{l}1 . .0 \text { to } 1.5 \\
\times 10^{-4}\end{array}$ \\
\hline Total fungi colonies & $\begin{array}{l}2.8 \text { to } 4.5 \times \\
10^{-5}\end{array}$ & Total E coli & $\begin{array}{ll}4.2 & \text { to } \\
5.0 \times 10^{-5}\end{array}$ \\
\hline
\end{tabular}

Table 3: Sewage effluent characters and microbial population in sewage during cropping season (mean of two years)

\section{Microbial estimation in soil and sewage water}

Freshly collected sewage water and soils irrigated with sewage and bore well water were estimated for total bacterial, fungal actinomycetes population by standard serial dilution plate count method using soil extract agar for bacteria [20], Martin rose Bengal agar for fungi [21] and Kuster's agar for actinomycetes [22]. Coliforms were estimated in sewage samples using eosine methylene blue (EMB). Plates were incubated at $28 \pm 2{ }^{\circ} \mathrm{C}$ in an incubator and colony counts were recorded after 3 to 6 days of incubation. The microbial populations were expressed as number of colony forming units per $\mathrm{g}$ soil or per $\mathrm{ml}$ sewage water.

\section{Enumeration of seed micro flora}

Ten grams of seeds were suspended in $90 \mathrm{ml}$ sterile distilled water in $150 \mathrm{ml}$ Erinemeyer flask. It was hand shaken for five minutes and six fold serial dilutions were made using the above" suspension. One $\mathrm{ml}$ of each of the dilution was transferred into sterile triplicate plates for the isolation of bacteria, fungi and actinomycetes using nutrients agar, rose bengal agar and Kuster's agar respectively. Petri plates were incubated at $29 \pm 1{ }^{\circ} \mathrm{C}$ and average microbial counts were recorded on the 5 th day of incubation [23].

\section{Estimation of soil enzymes activity}

Dehydrogenase enzyme activity in soil samples was determined by following the procedures as described by Casida et al. [24]. The values were expressed as mg TPF $\mathrm{g}^{-1} \mathrm{day}^{-1}$. Similarly alkaline phosphatase enzyme activity of soil samples was determined by procedure of Evazi and Tabutavbai [25]. And estimations were expressed as mg P-nitro phenol $\mathrm{g}^{-1} \mathrm{~h}^{-1}$.

\section{Statistical analysis}

The data of various parameters on soil and plant growth, biochemical, biophysical and yield attributes recorded for 2 years was analyzed in triplicates and subjected to ANOVA (analysis of variance) in accordance to field design using M-Stat package to quantify and evaluate the sources of variation. All the pooled data collected from split plot design analysis were subjected to Duncan's multiple range test (DMRT). The treatment means were compared at a significant level of 0.05 and ranking of treatments denoted by alphabets. The treatments denoted by different letters in the each column of tables and figures represent significantly different values among the treatments.

\begin{tabular}{|c|c|c|c|c|c|c|c|c|c|}
\hline \multirow[b]{2}{*}{ Treatment } & \multicolumn{3}{|l|}{$\mathrm{pH}$} & \multicolumn{3}{|c|}{$E C\left(d S ~ m^{-1}\right)$} & \multicolumn{3}{|c|}{$\begin{array}{l}\text { Organic } \\
(\%)\end{array}$} \\
\hline & $\begin{array}{l}\text { First } \\
\text { year }\end{array}$ & $\begin{array}{l}\text { Secon } \\
\text { d year }\end{array}$ & $\begin{array}{l}\text { Po } \\
\text { ole } \\
\text { d }\end{array}$ & $\begin{array}{l}\text { First } \\
\text { year }\end{array}$ & $\begin{array}{l}\text { Secon } \\
\text { d year }\end{array}$ & $\begin{array}{l}\text { Po } \\
\text { ole } \\
\text { d }\end{array}$ & $\begin{array}{l}\text { First } \\
\text { year }\end{array}$ & $\begin{array}{l}\text { Secon } \\
\text { d year }\end{array}$ & $\begin{array}{l}\text { Po } \\
\text { ole } \\
\text { d }\end{array}$ \\
\hline \multicolumn{10}{|l|}{ Land (L) } \\
\hline $\begin{array}{l}\text { Sewage } \\
\text { irrigated } \\
\left(L_{1}\right)\end{array}$ & $\begin{array}{l}7.27 \\
a\end{array}$ & $7.22 \mathrm{a}$ & $\begin{array}{l}7.2 \\
4 a\end{array}$ & $\begin{array}{l}0.42 \\
0 a\end{array}$ & $0.432 \mathrm{a}$ & $\begin{array}{l}0.4 \\
26 a\end{array}$ & $\begin{array}{l}0.90 \\
0 a\end{array}$ & $0.886 a$ & $\begin{array}{l}0.8 \\
93 a\end{array}$ \\
\hline $\begin{array}{l}\text { Borewell } \\
\text { irrigated } \\
\left(L_{2}\right)\end{array}$ & $\begin{array}{l}7.63 \\
b\end{array}$ & $7.68 \mathrm{~b}$ & $\begin{array}{l}7.6 \\
5 b\end{array}$ & $\begin{array}{l}0.34 \\
9 b\end{array}$ & $0.348 b$ & $\begin{array}{l}0.3 \\
48 b\end{array}$ & $\begin{array}{l}0.42 \\
8 b\end{array}$ & $0.442 b$ & $\begin{array}{l}0.4 \\
35 b\end{array}$ \\
\hline LSD (5\%) & $\begin{array}{l}0.11 \\
7\end{array}$ & 0.058 & $\begin{array}{l}0.0 \\
93\end{array}$ & $\begin{array}{l}0.05 \\
05\end{array}$ & 0.0523 & $\begin{array}{l}0.0 \\
365\end{array}$ & $\begin{array}{l}0.03 \\
28\end{array}$ & 0.0535 & $\begin{array}{l}0.0 \\
243\end{array}$ \\
\hline \multicolumn{10}{|c|}{ Source of irrigation (S) } \\
\hline $\begin{array}{l}\text { Sewage } \\
\text { water }\left(\mathrm{S}_{1}\right)\end{array}$ & $\begin{array}{l}7.35 \\
b\end{array}$ & $7.35 b$ & $\begin{array}{l}7.3 \\
5 c\end{array}$ & $\begin{array}{l}0.36 \\
7 a\end{array}$ & $0.400 \mathrm{a}$ & $\begin{array}{l}0.3 \\
84 a\end{array}$ & $\begin{array}{l}0.68 \\
2 a\end{array}$ & $0.728 a$ & $\begin{array}{l}0.7 \\
05 a\end{array}$ \\
\hline $\begin{array}{l}\text { Borewell } \\
\text { water }\left(\mathrm{S}_{2}\right)\end{array}$ & $\begin{array}{l}7.53 \\
a\end{array}$ & $7.59 a$ & $\begin{array}{l}7.5 \\
6 a\end{array}$ & $\begin{array}{l}0.40 \\
0 a\end{array}$ & $0.375 a$ & $\begin{array}{l}0.3 \\
88 a\end{array}$ & $\begin{array}{l}0.62 \\
8 b\end{array}$ & $0.585 \mathrm{c}$ & $\begin{array}{l}0.6 \\
06 c\end{array}$ \\
\hline $\begin{array}{l}\text { Alternate } \\
\left(\mathrm{S}_{3}\right)\end{array}$ & $\begin{array}{l}7.47 \\
a b\end{array}$ & $7.42 b$ & $\begin{array}{l}7.4 \\
4 b\end{array}$ & $\begin{array}{l}0.38 \\
6 a\end{array}$ & $0.392 a$ & $\begin{array}{l}0.3 \\
89 a\end{array}$ & $\begin{array}{l}0.68 \\
0 a\end{array}$ & $0.677 \mathrm{~b}$ & $\begin{array}{l}0.6 \\
79 b\end{array}$ \\
\hline LSD (5\%) & $\begin{array}{l}0.14 \\
1\end{array}$ & 0.088 & $\begin{array}{l}0.0 \\
51\end{array}$ & $\begin{array}{l}0.05 \\
5\end{array}$ & 0.068 & $\begin{array}{l}0.0 \\
31\end{array}$ & $\begin{array}{l}0.03 \\
9\end{array}$ & 0.039 & $\begin{array}{l}0.0 \\
18\end{array}$ \\
\hline
\end{tabular}

Table 4: Soil reaction $(\mathrm{pH})$, electrical conductivity $\left(\mathrm{dS} \mathrm{m}^{-1}\right)$ and organic carbon (\%) after harvest of crop as influenced by types of lands and sources of irrigation (mean of two years) ( $a, b, c$ : Means followed by same letter do not differ significantly at 5 per cent level of significance) 


\section{Results and Discussion}

\section{Influence of type of land}

Bulk density soil was the lowest in sewage land $\left(1.23 \mathrm{Mg} \mathrm{m}^{-3}\right)$ compared to bore well irrigated land $\left(1.33 \mathrm{Mg} \mathrm{m}^{-3}\right)$ due to influence higher organic carbon accumulation over long period of sewage water irrigation. Sewage land (55.2\%) had a capacity to hold maximum water compared to bore well irrigated land $(50.8 \%)$ would be because of high porosity, low bulk density and better soil structure Table 3. Tripathi [26] also noticed improvement in soil properties Sewage land recorded the lowest soil $\mathrm{pH}$ (7.24) as a result of decomposition of added organic matter through sewage water during which organic acids and $\mathrm{CO}_{2}$ must have been produced by soil microorganisms and those have been responsible for reduction in soil $\mathrm{pH}$ Table 4. Olaniya [27] also found decreased bulk density and increased electrical conductivity of soil due to application of municipal wastes. Sewage land increased the EC of soil significantly $\left(0.43 \mathrm{dS} \mathrm{m}^{-1}\right)$. Increased EC in sewage land could be due to addition of salts of chlorides and sulphates through sewage water. Improvement in soil physical properties due to sewage irrigation was also noticed by Dodolina [28] and Salakinkop et al. [29]. Sewage land $(0.89 \%)$ accumulated significant and twice the organic carbon that was recorded in the bore well irrigated land (0.43\%) (Table 5 and Figure 1).

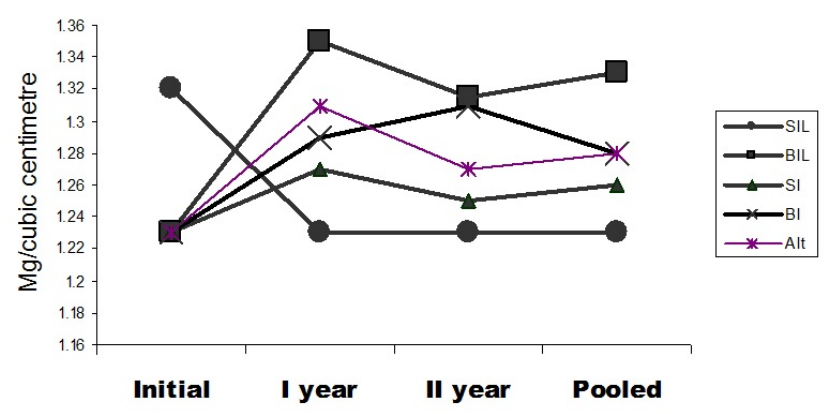

Figure 1: Organic Carbon as influenced by type of lands and sources of irrigation.

Biological activities and their influence on performance of wheat crop were studied in two types of lands Enumeration of colony forming units in the soil showed significantly higher bacterial and fungal population in sewage irrigated land compared to bore well irrigated land Table 4. Unnamalai et al. [30] also noticed increased colony farming units of microbes in industry wastes applied plots and sewage farms compared to control. Improved organic matter and nutrient status contributed by long term sewage irrigation encouraged the luxurious growth of micro-organisms and thereby enhanced enzymatic activities in sewage irrigated land. Stademan [31] noticed increased enzymatic activities in sewage sludge and pig slurry applied land. Alkaline phosphatase and acid phosphatase enzymes are responsible for converting organic phosphorus into available form. Both these enzymes were present significantly higher concentration in sewage irrigated land compared to bore well irrigated land. The concentration of alkaline phosphatase enzyme was almost double the concentration of acid phosphatase in both years. This was due to influence of soil $\mathrm{pH}$ on the relative dominance alkaline phosphatase producing micro-organisms. Presence of higher concentration phosphatase enzyme indicates more population of phosphorus solubilising micro-organisms.

\begin{tabular}{|c|c|c|c|c|c|c|}
\hline \multirow[b]{2}{*}{ Treatment } & \multicolumn{3}{|c|}{ MWHC (\%) } & \multicolumn{3}{|c|}{$\mathrm{BD}\left(\mathrm{Mgm}^{-3}\right)$} \\
\hline & $\begin{array}{l}\text { First } \\
\text { year }\end{array}$ & $\begin{array}{l}\text { Second } \\
\text { year }\end{array}$ & $\begin{array}{l}\text { Pool } \\
\text { ed }\end{array}$ & $\begin{array}{l}\text { First } \\
\text { year }\end{array}$ & $\begin{array}{l}\text { Second } \\
\text { year }\end{array}$ & $\begin{array}{l}\text { Pool } \\
\text { ed }\end{array}$ \\
\hline \multicolumn{7}{|l|}{ Land (L) } \\
\hline $\begin{array}{l}\text { Sewage irrigated } \\
\left(L_{1}\right)\end{array}$ & $55.85 a$ & $54.58 a$ & $\begin{array}{l}55.21 \\
a\end{array}$ & $1.23 a$ & $1.23 a$ & $1.23 a$ \\
\hline $\begin{array}{l}\text { Bore well irrigated } \\
\left(L_{2}\right)\end{array}$ & $51.17 \mathrm{~b}$ & $50.55 b$ & $\begin{array}{l}50.86 \\
b\end{array}$ & $1.35 b$ & $1.315 b$ & $1.33 \mathrm{~b}$ \\
\hline LSD (5\%) & 1.745 & 3.248 & 2.014 & 0.088 & 0.023 & 0.085 \\
\hline \multicolumn{7}{|c|}{ Source of irrigation (S) } \\
\hline Sewage water $\left(S_{1}\right)$ & $53.72 a$ & $52.92 a$ & $\begin{array}{l}53.32 \\
a\end{array}$ & $1.27 a$ & $1.25 a$ & $1.26 a$ \\
\hline $\begin{array}{l}\text { Bore well water } \\
\left(\mathrm{S}_{2}\right)\end{array}$ & $53.06 a$ & $51.59 a$ & $\begin{array}{l}52.32 \\
a\end{array}$ & $1.29 a$ & $1.31 \mathrm{a}$ & $1.28 \mathrm{a}$ \\
\hline Alternate $\left(\mathrm{S}_{3}\right)$ & $53.76 a$ & $53.19 a$ & $\begin{array}{l}53.47 \\
a\end{array}$ & $1.31 \mathrm{a}$ & $1.27 a$ & $1.28 \mathrm{a}$ \\
\hline LSD (5\%) & 2.137 & 3.978 & 1.457 & 0.111 & 0.039 & 0.036 \\
\hline
\end{tabular}

Table 5: Maximum water holding capacity (\%) and bulk density (Mg $\mathrm{m}^{-3}$ ) of soil after harvest of crop as influenced by types of lands and sources of irrigation (mean of two years) a, b: Means followed by same letter do not differ significantly at 5 per cent level of significance. $\left({ }^{*} \mathrm{LSD}\right.$ applicable to Duncan's multiple range tests at 5 per cent; ${ }^{*}$ Means followed by same letters do not differ significantly)

The organic form of phosphorus was converted to inorganic form as evidenced by improved available phosphorus in sewage irrigated land $\left(30.9 \mathrm{~kg} \mathrm{ha}^{-1}\right)$ compared to bore well irrigated land $(24.5 \mathrm{~kg}$ $\left.\mathrm{ha}^{-1}\right)$.Therefore there was positive and significant correlation between phosphates enzyme activity in soil and yield of wheat crop $\left(0.62^{*}\right)$. Yield of crop depend on many growth factors which mainly include soil, climatic and plant parameters. In the present study soil properties mainly water holding capacity, bulk density and nutrient availability were improved resulting increased grain yield of wheat crop. Further growth and yield attributes of crop were also improved in sewage irrigated land compared to bore well irrigated land.

Similarly higher activity of microbes denoted by increased concentration of dehydrogenase enzyme was noticed in sewage irrigated land compared to bore well irrigated land Table 6 . Shrikanthimathi and Salakinkop and Hunshal [32,33] also noticed higher activity of dehydrogenase enzyme and faster decomposition of organic material in sewage amended soil than unamended soil. This enzyme is responsible for decomposition of organic matter. The higher organic carbon content in sewage irrigated land $(0.89 \%)$ increased the activity of dehydrogenase enzyme and thereby improved available nutrient status especially nitrogen in sewage irrigated land. There is well established doubt that sewage water and sewage irrigated land pollute the grains by microbial contamination. Roger and Hessettine [34] recorded higher population of bacteria on surface of wheat grain followed by fungi and actinomycetes. Present study revealed that neither sewage water nor sewage irrigated land did increase the bacterial, fungal and actinomycetes colonies on grain surface 
compared to bore well water Table 4 . But normal population of phyllosphere micro flora was observed on wheat grain surface.

\begin{tabular}{|l|l|l|l|l|l|l|}
\hline Treatment & $\begin{array}{l}\text { Bacter } \\
\text { ia }\end{array}$ & $\begin{array}{l}\text { Fun } \\
\text { gi }\end{array}$ & $\begin{array}{l}\text { Actinomyce } \\
\text { tes }\end{array}$ & $\begin{array}{l}\text { Bacter } \\
\text { ia }\end{array}$ & $\begin{array}{l}\text { Fung } \\
\text { i }\end{array}$ & $\begin{array}{l}\text { Actinomyce } \\
\text { tes }\end{array}$ \\
\hline Land & \multicolumn{2}{|l|}{ On surface of grains } & \multicolumn{3}{|l|}{ In the root zone of crop } \\
\hline $\begin{array}{l}\text { Sewage } \\
\text { irrigated }\end{array}$ & $34.67 \mathrm{a}$ & $\begin{array}{l}7.31 \\
\mathrm{a}\end{array}$ & $2.69 \mathrm{a}$ & $4.368 \mathrm{a}$ & $\begin{array}{l}12.88 \\
\mathrm{a}\end{array}$ & $28.83 \mathrm{a}$ \\
\hline $\begin{array}{l}\text { Borewell } \\
\text { irrigated }\end{array}$ & $33.37 \mathrm{~b}$ & $\begin{array}{l}6.65 \\
\mathrm{~b}\end{array}$ & $2.34 \mathrm{~b}$ & $3.365 \mathrm{~b}$ & $\begin{array}{l}12.22 \\
\mathrm{~b}\end{array}$ & $27.17 \mathrm{~b}$ \\
\hline CD (5\%) & 2.35 & 1.33 & 0.87 & 0.325 & 0.259 & 2.162 \\
\hline $\begin{array}{l}\text { Source } \\
\text { irrigation }\end{array}$ & of & & & & & \\
\hline Sewage & $33.88 \mathrm{a}$ & $\begin{array}{l}6.81 \\
\mathrm{a}\end{array}$ & $2.52 \mathrm{a}$ & $4.100 \mathrm{a}$ & $\begin{array}{l}12.81 \\
\mathrm{a}\end{array}$ & $28.41 \mathrm{a}$ \\
\hline Borewell & $33.83 \mathrm{a}$ & $\begin{array}{l}7.04 \\
\mathrm{a}\end{array}$ & $2.50 \mathrm{a}$ & $3.557 \mathrm{c}$ & $\mathrm{b}$ & $27.14 \mathrm{a}$ \\
\hline Alternate & $34.33 \mathrm{a}$ & $\begin{array}{l}7.10 \\
\mathrm{a}\end{array}$ & $2.54 \mathrm{a}$ & $3.943 \mathrm{a}$ & $\begin{array}{l}12.64 \\
\mathrm{a}\end{array}$ & $28.46 \mathrm{a}$ \\
\hline CD (5\%) & $\mathrm{NS}$ & $\mathrm{NS}$ & $\mathrm{NS}$ & 0.2266 & 0.025 & $\mathrm{NS}$ \\
\hline
\end{tabular}

Table 6: Population of bacteria, fungi and actinomycetes on grain surface (no. $\times 10^{-4}$ ) and in soil sample (no. x $10^{-5} \mathrm{~g}^{-1}$ ) after harvest of crop as influenced by types of lands and sources of irrigation (mean of two years) a, b, c: Means followed by same letter do not differ significantly at 5 per cent level of significance.

Therefore sewage irrigated land recorded higher grain yield (4368 $\mathrm{kg} \mathrm{ha}^{-1}$ ) and protein per cent (12.88) compared to bore well irrigated land which produced $3365 \mathrm{~kg} \mathrm{ha}^{-1}$ grains, 12.20 per cent protein content in grains Table 7 which could be due to increased soil productivity as evidenced by higher microbial population. Their enzymatic activities, organic matter and nutrients status in sewage irrigated land. Similarly improved yield of rice was noticed with use urban compost $[35,36]$.

\section{Influence of sources of irrigation}

Sources of irrigation did not influence the bulk density. The highest bulk density of soil was noticed in bore well irrigated land under bore well irrigation and was on par with all interactions in bore well irrigated land Table 3 and Figure 2. Soil $\mathrm{pH}$ reduction was more in sewage water irrigation than alternate irrigation. Bore well water irrigation recorded the highest $\mathrm{pH}$ (7.56). Treatment interactions in sewage land recorded lower $\mathrm{pH}$ than interactions in bore well irrigated land. Sources of irrigation did not differ significantly to alter the soil electricity (EC) Table 4 . Sewage water irrigation revealed the highest organic carbon content followed by alternate irrigation, whereas bore well water irrigation recorded the lowest. Higher number of soil bacterial and fungal colonies was noticed in both sewage and alternate irrigation than bore well water irrigation. Actinomycetes population did not influence by the sources of irrigation. Sewage irrigation supported the population of $\mathrm{N}$-fixers and fungi involved in organic matter decomposition [11]. Microbes helped in composting of organic matters [37]. Deficiency of micronutrients especially $\mathrm{Zn}, \mathrm{Fe}, \mathrm{Cu}$ and $\mathrm{Mn}$ is common in black cotton soil due to intensive cultivation of HYV, hybrids, mono cropping and non-availability of sufficient organic sources of nutrient to correct the deficiency. Sewage effluent in present study corrected these deficiency and also supplemented the part of the major plant nutrients as effluent water contain considerably good amount of total N (29.2 ppm), total P (13.1ppm), total K (54.7 $\mathrm{ppm}), \mathrm{Zn}(0.31 \mathrm{ppm}), \mathrm{Cu}(0.16 \mathrm{ppm}), \mathrm{Fe}(1.24 \mathrm{ppm})$ and $\mathrm{Mn}(0.15$ $\mathrm{ppm})$. The nutrient content of the effluent used for irrigating wheat crop is presented Table 1. By looking at BOD levels, it was said that domestic originated sewage of present study was weak and fit for irrigation. Sewage effluent having BOD within 100-150 ppm was preferred for irrigation [38] and for wheat crop, it could be $260 \mathrm{ppm}$. Thus sewage water irrigation at critical stages of crops acted as top dressed fertilizers and thereby enhanced the activity of bacteria, fungi and actinomycetes. Organic matter and nutrients present in sewage water acted as source of carbon and energy for microbes due to which there was maximum bacterial and fungal colonies in sewage and alternate irrigation treatments. Further, increased beneficial microbes must have also contributed to available nutrient pool as they decompose the organic matter added through sewage Figure 3.

\begin{tabular}{|c|c|c|c|c|c|c|c|}
\hline \multirow[b]{2}{*}{ Treatment } & \multicolumn{3}{|c|}{$\begin{array}{l}\text { Alkaline phosphatase ( } \mathrm{mg} \\
\left.\text { P-nitrophenol } \mathrm{g}^{-1} \mathrm{~h}^{-1}\right)\end{array}$} & \multicolumn{3}{|c|}{$\begin{array}{l}\text { Dehdrogenase } \quad \text { (mg } \\
\text { TPF g }^{-1} \text { day }^{-1} \text { ) }\end{array}$} & \multirow{2}{*}{\begin{tabular}{|l|}
$\begin{array}{l}\text { Avail. } \\
\left(\mathrm{Kg} \mathrm{ha}^{-1}\right)\end{array}$ \\
Pooled
\end{tabular}} \\
\hline & $\begin{array}{l}\text { First } \\
\text { year }\end{array}$ & $\begin{array}{l}\text { Second } \\
\text { year }\end{array}$ & $\begin{array}{l}\text { Poole } \\
\text { d }\end{array}$ & $\begin{array}{l}\text { First } \\
\text { year }\end{array}$ & $\begin{array}{l}\text { Secon } \\
\text { d year }\end{array}$ & $\begin{array}{l}\text { Poo } \\
\text { led }\end{array}$ & \\
\hline \multicolumn{8}{|l|}{ Land } \\
\hline $\begin{array}{l}\text { Sewage } \\
\text { irrigated }\end{array}$ & $99.77 a$ & $107.41 a$ & $\begin{array}{l}103.59 \\
a\end{array}$ & $\begin{array}{l}34.83 \\
\mathrm{a}\end{array}$ & $42.38 a$ & $\begin{array}{l}38 . \\
61 a\end{array}$ & $30.98 a$ \\
\hline $\begin{array}{l}\text { Borewell } \\
\text { irrigated }\end{array}$ & $88.45 b$ & $88.92 b$ & $88.19 b$ & $\begin{array}{l}27.17 \\
\mathrm{~b}\end{array}$ & $28.30 \mathrm{~b}$ & $\begin{array}{l}27 . \\
74 \mathrm{~b}\end{array}$ & $24.50 \mathrm{~b}$ \\
\hline $\mathrm{CD}(5 \%)$ & 3.8 & 5.42 & 2.79 & 2.15 & 4.28 & $\begin{array}{l}2.1 \\
1\end{array}$ & 1.87 \\
\hline
\end{tabular}

\section{Source of irrigation}

\begin{tabular}{|l|l|l|l|l|l|l|l|}
\hline Sewage & $96.92 \mathrm{~b}$ & $101.00 \mathrm{a}$ & $98.94 \mathrm{~b}$ & $\begin{array}{l}32.50 \\
\mathrm{a}\end{array}$ & $38.15 \mathrm{a}$ & $\begin{array}{l}35 . \\
33 \mathrm{a}\end{array}$ & $29.52 \mathrm{a}$ \\
\hline Borewell & $83.74 \mathrm{c}$ & $86.66 \mathrm{~b}$ & $85.20 \mathrm{c}$ & $\begin{array}{l}28.63 \\
\mathrm{~b}\end{array}$ & $32.50 \mathrm{~b}$ & $\begin{array}{l}30 . \\
56 \mathrm{c}\end{array}$ & $25.48 \mathrm{~b}$ \\
\hline Alternate & $101.70 \mathrm{a}$ & $105.40 \mathrm{a}$ & $\begin{array}{l}103.50 \\
\mathrm{a}\end{array}$ & $\begin{array}{l}31.88 \\
\mathrm{a}\end{array}$ & $\begin{array}{l}35.39 \mathrm{a} \\
\mathrm{b}\end{array}$ & $\begin{array}{l}33 . \\
63 \mathrm{~b}\end{array}$ & $28.23 \mathrm{a}$ \\
\hline $\mathrm{CD}(5 \%)$ & 4.65 & 4.99 & 2.2 & 1.66 & 3.98 & $\begin{array}{l}1.4 \\
2\end{array}$ & 1.47 \\
\hline
\end{tabular}

Table 7: Alkaline phosphatase and acid phosphatase activity (mg Pnitrophenol $\mathrm{g}^{-1} \mathrm{~h}^{-1}$ ) in soil as influenced by types of lands and sources of irrigation(mean of two years) a, b, c: Means followed by same letter do not differ significantly at 5 per cent level of significance.

The maximum decomposition of organic matter could be evidenced by significantly the highest dehydrogenase activity in sewage water irrigation ( $35.3 \mathrm{mg} \mathrm{TPF} \mathrm{g}{ }^{-1} \mathrm{day}^{-1}$ ) followed by alternate irrigation $\left(33.6 \mathrm{mg}\right.$ TPF $\left.\mathrm{g}^{-1} \mathrm{day}^{-1}\right)$. The sewage water irrigation recorded higher acid and alkaline phosphatase activity as sewage itself was good source of organic phosphorus (11.9 - 17.3 ppm) Table 6. Yield of wheat crop positively correlated with enzyme activities of microbes Figure 4 . 


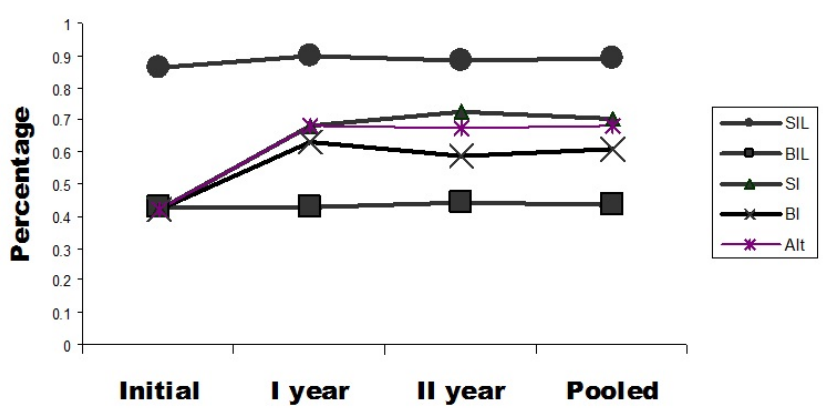

Figure 2: Bulk density as influenced by type of lands and sources of irrigation.

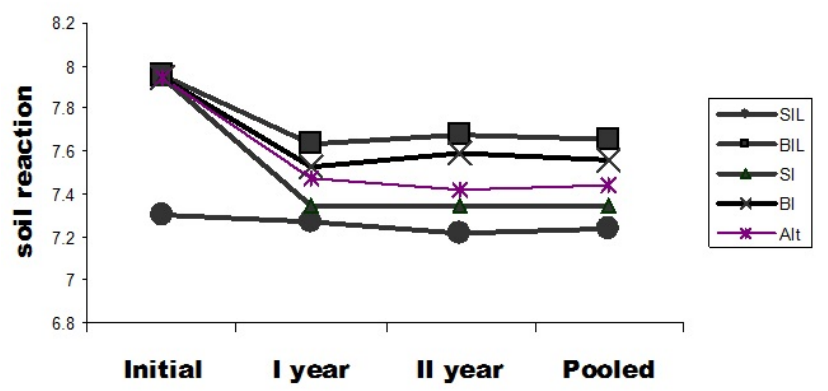

Figure 3: $\mathrm{pH}$ as influenced by type of lands and sources of irrigation.

Sources of irrigation did not differ significantly with respect to bacterial, fungal and actinomycetes population on grain surface Table 5. Normal populations of phyllosphere microflora were observed. Radhakrishna [39] also isolated population of bacteria from sorghum ears at different stages of maturation under sewage irrigation.

Sources of irrigation differed significantly having the highest grain yield in sewage irrigation (4100 kg ha-1) followed by alternate irrigation (3940 kg ha-1) Table 7. The conjunctive use of sewage and good water has also been recommended to improve the yield of many crops without pollution effect $[40,41]$. The bore well water irrigation recorded the lowest grain yield $\left(3550 \mathrm{~kg} \mathrm{ha}^{-1}\right)$.

Wheat grain protein and gluten contents were also the highest in sewage irrigation followed by alternate irrigation compared to bore well irrigation. Bore well irrigation did not increase the protein content and subsequently the gluten because of limited supply of nitrogen. Whereas, in sewage irrigation and alternate irrigation, the nitrogen contribution would have increased the nitrogen content in grain and ultimately protein and grain yield.

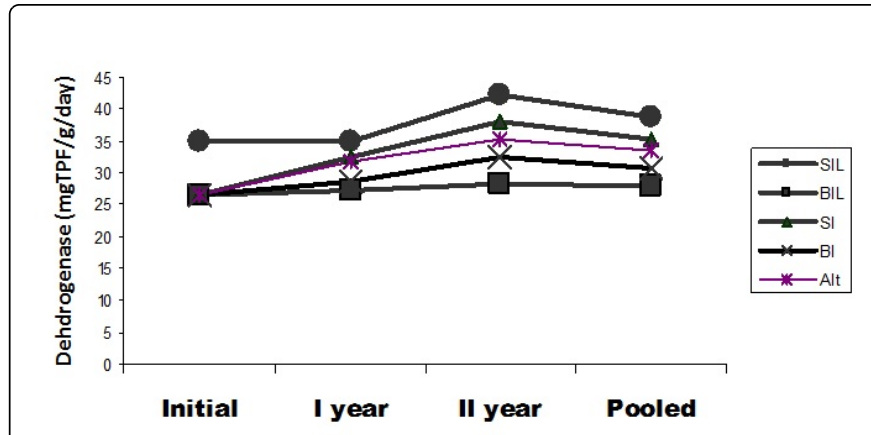

Figure 4: Dehydrgenase activity as influenced by type of lands and sources of irrigation.

\section{References}

1. Mara DD (1976) Sewage treatment in hot climates. Willey.

2. Talashilkar SC (1989) Recycling of urban wastes in agriculture. Soil pollution and microorganisms.

3. Skulte BF (1956) Irrigation with sewage effluent. Sewage Industrial Waste 28: 36-46.

4. Salakinkop SR, Hunshal CS (2008a) Influence of long term utilization of domestic sewage on performance of wheat and health of farmers. Journal of Ecobiology 22: 45-51.

5. Cook WB (1969) The distribution of fungal in waste stabilization pond system. Ecology 50: 689-694.

6. Butler EE (1960) Pathogenicity and taxonomy of Geotrichum candidum. Phytopathology 50: 665-672.

7. Barman SC (1994) A comparative study of mature plants grown in polluted and unpolluted soil using different pulses and oil seeds. In: Proceedings of symposium held at Shantineketan, India.

8. Day AD, Mc-Fadyen JA, Tucker TC, Cluff CB (1979) Commercial production of wheat grain irrigated with municipal waste water and pump water. J Environ Quality 8: 403-406.

9. Singh D, Rana DS, Pandey RN, ChauhanI S (1995) Yield response of fodder sorghum, maize and cowpea to varying NPK doses under waste water irrigation on mollisols of Western Uttar Pradesh. Annals of Agricultural Research 16: 522-524.

10. Hussain G, Al-Jaloud and Karimullas (1996) Effect of treated effluent irrigation and $\mathrm{N}$ on yield and $\mathrm{N}$ use efficiency of wheat. Agric Water Manag 30: 175-184.

11. Leela S (1981) Studies on micro-organisms associated with sewage irrigated soils and crop plants.

12. Van Donsel DJ, Geldreich EE, Clarke NA (1967) Applied Microbiology 15: $1362-1370$.

13. Salakinkop SR, Hunshal CS (2008b) Influence of sewage irrigation on biological activities in soil cropped with wheat (Triticum aestivum L.) Journal of Ecobiology 22: 159-166.

14. Piper CS (1950) Soil and Plant Analysis, University of Adelaide, Australia.

15. Black CA (1965) Methods of Soils Analysis Part II Chemical and Microbial Properties. American Society of Agronomy Inc, Madison.

16. Jackson ML (1967) Soil Chemical Analysis Prentice Hall of India Pvt Ltd New Delhi.

17. Subbaih BV, Asija GL (1956) A rapid procedure for the estimation of available nitrogen in soils. Current Sciences 25: 259-260.

18. Olsen RV, Roscoe EJr (1982) Phosphorus. Methods of Soil Analysis, Part II. American Society of Agronomy. 
Citation: Salakinkop SR, Hunshal CS, Patil SL (2014) Peri-Urban Vertisol Properties as Influenced by Sewage and Bore Well Water Irrigation to Wheat (Triticum aestivum L.). J Civil Environ Eng 4: 146. doi:10.4172/2165-784X.1000146

Page 7 of 7

19. Greenberg (1989) Standard Methods for the Examination of Water and Waste Water. 17th Edition, American Public Health Association, New York.

20. Bunt JS, Rovira AD (1955) Microbiological studies of Sub-Antratic soils. Journal of Soil Science 6: 119-128.

21. Martin JP (1950) Use of acid, rose Bengal and streptomycin in plate method for estimating soil fungi. Soil science 69: 215-232.

22. Kuster E, William ST (1964) Selection of media for isolation of streptomycetes. Nature. 202: 928-929.

23. Waksman SA (1927) Principles of Soil Microbiology, Bailliore, Tandal and Cox, London.

24. Casida LE, Klein DA, Santoro T (1964) Soil Dehdrogenase activity. Soil Science 98: 371-376.

25. Evazi Z, Tabatabai MA (1977) Phoshatase in soils. Soil Biology and Biochemistry 9: 167-172.

26. Tripathi BD Kumari D, Dwivedi RL (1988) Effect of sewage irrigation on soil properties and yield of potato. Geol. and Ecol. Tropics. 12: 133-141.

27. Olaniya MS, Sur MS, Bhinde AD, Swarkar SN (1998) Heavy metals pollution of agricultural soil and vegetation due to application of municipal solid waste. Indian Journal of Environmental Health 40: 160-168.

28. Dodolina VT (1971) Effect of irrigation with sewage on the fertility of sod podzolic soils. Soviet Soil Science 3 : 548-555

29. Salakinkop SR, Shivaprasad P, Raguramulu Y, Naidu R (2003) Composting of coffee pulp. Journal of Coffee Research 31: 153-160.

30. Unnamalai CT, Ganapathy M and Angayarkanni A (2004) Effect of industrial and urban solid wastes on microbial population in low land rice soil. J. Ecobiol. $16: 299-302$.

31. Stadelmann FX (1982) Effect of increasing amount of sewage sludge and pig slurry in field experiment. Schweizerische land wirstschaffliche 21 : 239-259.
32. Srikanthimathi B (1990) Effect of polluted Vrishabharathy river water irrigation on soil physico-chemical and microbial properties and on plant growth.

33. Salakinkop SR, Hunshal CS (2008c) Studies on Production and Characterization of Enriched Urban Waste Composts and their influence on Crops Productivity. Journal of Environmental Sciences \& Engineering 50: 83-88.

34. Roger FR, Hessetine CW (1978) Microflora of wheat and wheat flour from six areas of United States of America. Cereal Chemistry 55: 889-898.

35. Cambell WF, Miller RW, Reynolds JH, Schreeg TM (1983) Alfalfa, sweet corn and wheat responses to long-term application of municipal waste water to crop land. J Environ Quality 12: 243-249.

36. Yoganand SB, Reddy VC (2004) Growt and sustainability of rice varieties as influenced by urban compost and inorganic fertilizers. J Ecobiol 16: 279-285.

37. Salakinkop SR, Shivaprasad P, Raguramulu Y (2005) Panchagavya - A organic formulationfor Bio-composting of farm wastes in coffee plantations. Indian Coffee, 62: 15-16.

38. Juwarkar AS (1992) Biological and industrial wastes as source of plant nutrients. Fertilizer, Organic manure, Recyclable wastes and Biofertilizers.

39. Radhakrishna P (1977) Phyllosphere microflora of sorghum with special reference to the incidence of Azotobacter spp.

40. Nagaraja DN, Krishnamurthy K (1988) Rice varieties for sewage effluent and without fertilizers. J Agri Sci 22: 433-435.

41. Monte H, Sousa (1992) Effect on crops of irrigation with facultative pond effluent. Water Science Tech 26: 1603-1613. 